\title{
The Acute Toxicity of Nitrite Inhalants
}

\author{
Ronald W. Wood
}

\section{INTRODUCTION}

Alkyl nitrites produce a variety of effects when inhaled. Except in the context of anginal pain or as an antidote to cyanide poisoning, these effects cannot be construed as having therapeutic utility. A number of demonstrable risks accompany the inhalation of these materials, and this chapter will review the acute hazards associated with the nonmedical use of these chemicals. Aside from the spectrum of effects desired by the user, there are less desirable "side effects" as well as frank injuries associated with the use of these products, including skin and tracheobronchial irritation; bum injuries; acute toxicity mediated by hypokinetic anoxia, methemoglobinemia, and associated disorders of blood and blood-forming organs; and the induction of a substance abuse disorder.

\section{DESIRED ACUTE EFFECTS AND UNDESIRED SIDE EFFECTS}

Inhalation of high concentrations of nitrites relaxes smooth muscle: the consequent intense peripheral vasodilation produces flushing, a fall in blood pressure, and a reflex increase in heart rate to maintain perfusion of vital organs (Haley 1980). These effects are accompanied by feelings of warmth, rapid pulse, and throbbing sensations. Volatile nitrites are frequently used as an adjunct to sexual behavior, because of their smooth muscle effects, nitrites can reduce sphincter tone and alter tumescence. The vasodilation is accompanied by heat loss and a subsequent chill. Headache, nausea, and fainting are common sequelae of nitrite inhalation. 


\section{Skin and Tracheobronchial Irritation}

Skin contact with commercial products containing butyl nitrite can produce a crusty lesion at the site. Repetitive use of the material can lead to a proliferation of these lesions around the nose and lip (Fisher et al. 1981; Fisher 1984; Romaguera and Grimalt 1982) and has been reported around the penis, the scrotum, and elsewhere (Bos et al. 1985). The latter report suggests that a true allergic response to these materials may occur.

The irritating properties of these materials are not confined to the skin and have manifested themselves in tracheobronchitis with erythema of sufficient severity to require hospitalization, and with complaints of cough, fever, mild hemoptysis, and exertional dyspnea (Covalla et al. 1981). Subchronic toxicity evaluations support concern about lung injury (McFadden and Maickel1985; Lynch et al. 1985).

\section{Burn Injuries}

Aikyl nitrites are flammable and explosive. At least one bum injury has been reported through the National injury Information Clearing House (NEISS data base) of the Consumer Product Safety Commission (CPSC), following the use of a room odorizer product near a candle. "This incident involved a 26- yearold male who opened a small bottle on a stand when it ignited, flamed up, and burned him. During this accident, the victim spilled some of the gymnasium room odorizer onto parts of the living room furnishings. As a result, part of an ottoman and small sections of the carpet were damaged. It is believed that the liquid gymnasium room odorizer ignited, as its vapors came into contact with a lighted cigarette in a nearby ash tray. The victim received bums on the left side of his nose and an area of his left cheek. The victim was also singed on his right arm, forehead and some parts of his hair" (CPSC memo from Schmettzer to Perez, July 11, 1977).

The materials are labeled with a warning of this hazard, which Is not to be underestimated; small quantities have been responsible for refrigerator explosions in laboratories, and larger quantities have been implicated in the largest fire in San Francisco since the earthquake of 1998 (Turner 1981). Despite these hazards, many of the products packaged in small vials with shrink-fit plastic comply with U.S. Postal Service regulations for the shipment of small quantities of flammable and explosive materials. 


\section{Acute Toxicity}

Whether inhaled or swallowed, nitrites can produce anoxic states. The administration of nitrites by any route can produce profound methemoglobinemia. Tissue anoxemia can result from methemoglobinemia (Darling and Roughton 1942; Lester and Greenburg 1944). Ascorbic acid and methylene blue may be effective prophylactic agents for nitrite poisoning if administered promptly, but laboratory studies offer little support for this in the case of isobutyl nitrite ingestion (McFadden and Maickel 1982). Prolonged administration of the materials may lead to several disorders of the Mood and blood-forming organs, including Heinz-body hemolytic anemia and splenomegaly (Romeril and Concannon 1981); increased spleen weight has been observed in mice chronically exposed to butyl nitrites (McFadden and Maickel 1985). The administration of nitrites can also produce hypokinetic anoxia, an oxygen starvation of vital organs secondary to sustained profound peripheral vasodilation, pooling of Mood in the extremities, and impaired vascular return (Wilkins et al. 1937).

A number of human anecdotes report on the acute toxicity of volatile nitrite "room odorizer" products and provide correlative observations that substantiate concern aroused by experimental work with laboratory animals. Severe methemoglobinemia can result from deliberate inhalation of room odorizer products (Home et al. 1979; Shesser et al. 1981; Guss et al. 1985). Ingestion can produce a more rapid and malignant methemoglobinemia than can inhalation and can be lethal (Dixon et al. 1981; Shesser et al. 1980; Shesser et al. 1981; Smith et al. 1980; Wason et al. 1980).

The acute toxicity of the alkyl nitrites has received attention in the laboratory and is relevant to the regulation of these materials in interstate commerce, including packaging and labeling requirements. A summary of these experimental findings is presented in table 1. Room odorizer products are currently considered to be "toxic" by inhalation or ingestion, although the oral toxicity of the material has not been evaluated adequately according to the CPSC. The materials display an unusually steep lethality function so that, in the effective range, small increments in dose produce large changes in the number of resultant deaths (Wood and Cox 1981; Klonne et al. 1987). In addition, there is a very narrow margin of safety between behaviorally effective and lethal concentrations (Rees et al. 1986). 
Users estimate they can derive 40 "doses" from a typical room odorizer, yielding approximately $0.2 \mathrm{ml}$ per self-administration (Israelstam et al. 1978). This estimate is neither a dose nor an exposure concentration, but a rate of loss of a volatile material from an open container. There have been no studies that describe either the absorbed dose or the exposure concentrations that are effective in producing smooth muscle relaxation, alterations in cardiovascular function, behavioral impairment, or self-administration under the brief exposure conditions typical of self-administration. However, Pryor et al. (1989) did expose rats to isobutyl nitrite for 15 to 60 seconds, at concentrations that increased gradually in the exposure chamber. The LC50s expressed as a peak concentration ranged from 4.5 to 4.8 percent. The slope of the lethality function was influenced by the rate of change of concentration. A constant concentration-time product relationship was not obtained in this study, or in that of Klonne et al. (1987), suggesting that the dramatic acute effects of the agent may alter the pharmacokinetics and exaggerate the toxicity of these agents.

For some of the aliphatic nitrites, the alcohol from which they are synthesized may contribute significantly to their toxicity when injected or ingested. In addition, the alkyl nitrites are metabolized to nitrite ions and the corresponding alcohol, which may lead to delayed deaths or hepatotoxicity. n-Butyl alcohol has an oral median lethal dose $\left(\mathrm{LD}_{50}\right)$ for the male rat of $790 \mathrm{mg} / \mathrm{kg}$ (Purchase 1969), in contrast to $13,600 \mathrm{mg} / \mathrm{kg}$ for ethanol (Smyth et al. 1941). In an investigation of several highly pure butyi nitrites and their alcohols given to mice intraperitoneally, set- and tert-butyl nitrites were found to have significant delayed toxicity; the toxicity of the alcohols by the same route was also delayed, and the $\mathrm{LD}_{50}$ ranged from 254 (n-butyl) to $544 \mathrm{mg} / \mathrm{kg}$ (isobutyl) 7 days after administration (Maickel and McFadden 1979).

\section{SUBSTANCE ABUSE DISORDERS}

There is clear evidence that volatile nitrites are used as drugs of abuse. National surveys indicate that high school seniors and adults not only have used alkyl nitrites as drugs, but also that 7.9 to 11.1 percent of high school seniors from 1979 to 1985 reported having tried these drugs in their lifetime (Johnston et al. 1986). The incidence of deliberate use by homosexual men has been greater and is discussed in more detail shortly. Lowry (1980) conservatively estimated that 250 million recreational doses a year were consumed in the United States (Lowry 1982). 
Volatile nitrites are persistently self-administered by people. Israelstam et al. (1978) interviewed 150 users of isobutyl nitrite and reported that users who administered nitrites did so from three to six times per "occasion"; the number of occasions ranged from only once to four times a week. The duration that this frequency of selfadministration was maintained was unspecified. Goedert et al. (1982), in an attempt to determine if volatile nitrites alter immune function, studied 17 men; 10 were described as regular users, inhaling nitrites from 1 to 20 times per month; 4 had used nitrites for longer than 6 years. Romeril and Concannon (1981) presented two cases, each of which reported 20 sniffs per occasion, two to three times per week, for either 3 or 24 months. Fisher et al. (1981) reported on two men who stated that they were "in the habit" of inhaling butyl nitrite and continued to do so during the 6-week period that they were seen by a physician.

According to the nosological scheme of the Diagnostic and Statistical Manual (DSM III) of the American Psychiatric Association, one definitional criterion of "substance abuse" is a duration of pathological use for at least 1 month; several of the cases described above meet this criterion. Other than the duration of use, definitional criteria for "pathological use" vary with the substance abused but may include episodes of complication due to substance intoxication, e.g., alcoholic blackouts, opioid overdose; need for daily use of the substance for adequate functioning; and continuation of substance use despite a serious physical disorder that the individual knows is exacerbated by use of the substance. Examples from the literature fulfilling these criteria follow.

\section{Compications Due to Substance Intoxication}

Shesser et al. (1981) report a hospital admission following several hours of continuous inhalation of an isobutyl nitrite preparation. The patient was alert and combative, and the parents sought to have the patient admitted to the hospital because of mental status change and cyanosis. The patient admitted to having had several drinks of alcohol. Treatment of the patient with oxygen and intravenous methylene blue and ascorbic acid resulted in alleviation of the cyanosis; with the patient becoming calmer and reoriented. Covalla et al. (1981) report a hospital admission for severe tracheobronchitis following the.patient's inhalation, with a friend, of two bottles of LockerRoom in a week's time. Hi friend developed a similar but less severe illness. The cases in the following paragraph also constitute complications of substance intoxication. 


\section{Continuation of Substance Use Despite a Serious Physical Disorder Exacerbated by Use of the Substance}

Home et al. (1979) report emergency room admission on two separate occasions of a $25 y$ ear-old man after he inhaled butyl nitrite. The occurrence of clinically significant methemoglobinemia was not sufficient to deter self-administration in this individual. In a survey of 255 experienced users (Lowry 1979), 10 percent had experienced nasal irritation at least once, and 5 percent had experienced nausea or temporary loss of erection. These negatlve effects were associated with "overuse" (emphasis Lowry's). Fisher et al. (1981) report several cases of facial dermatitis due to butyl nitrite inhalation. Two of the three cases reported that they were "in the habit of inhaling butyl nitrite," and continued to do so during the 6-week period in which the dermatitis was evident. The skin lesions cleared when nitrite use was terminated.

\section{Need for Daily Use of the Substance for Adequate Functioning}

Sigell et al. (1978) interviewed an unspecified number of users, some of whom claimed that they were no longer able to perform sexually without the use of these drugs. Everett (1975) has made a similar assertion.

\section{CONCLUSION}

Research funded by the National Institute on Drug Abuse (NIDA) has demonstrated that drugs abused repetitively by humans are selfadministered by animals; drugs that are abused sporadically by humans (most hallucinogens), or not at all (major tranquilizers), are not taken by laboratory animals. Thus, there is a pharmacologic sine qua non for the ability of drugs to maintain self-administration: in the absence of intrinsic abuse potential, humans will not persistently abuse a drug. Although there have been no laboratory investigations using animal self administration preparations, volatile nitrites have abuse potential because they would not generate persistent human self-administration in its absence.

The extrapharmacologic determinants of substance abuse are of great importance; in this case, the pattern of distribution, availability, and promotion of materials in commerce play predominant roles in elevating the abuse liability of the volatile nitrites. The pattern of distribution of volatile nitrites is typical of a free market with access to the mails and the right to advertise. The interruption of this 
pattern of distribution would reduce the abuse liability of these agents.

TABLE 1. Acute toxicity of akyl nitrites

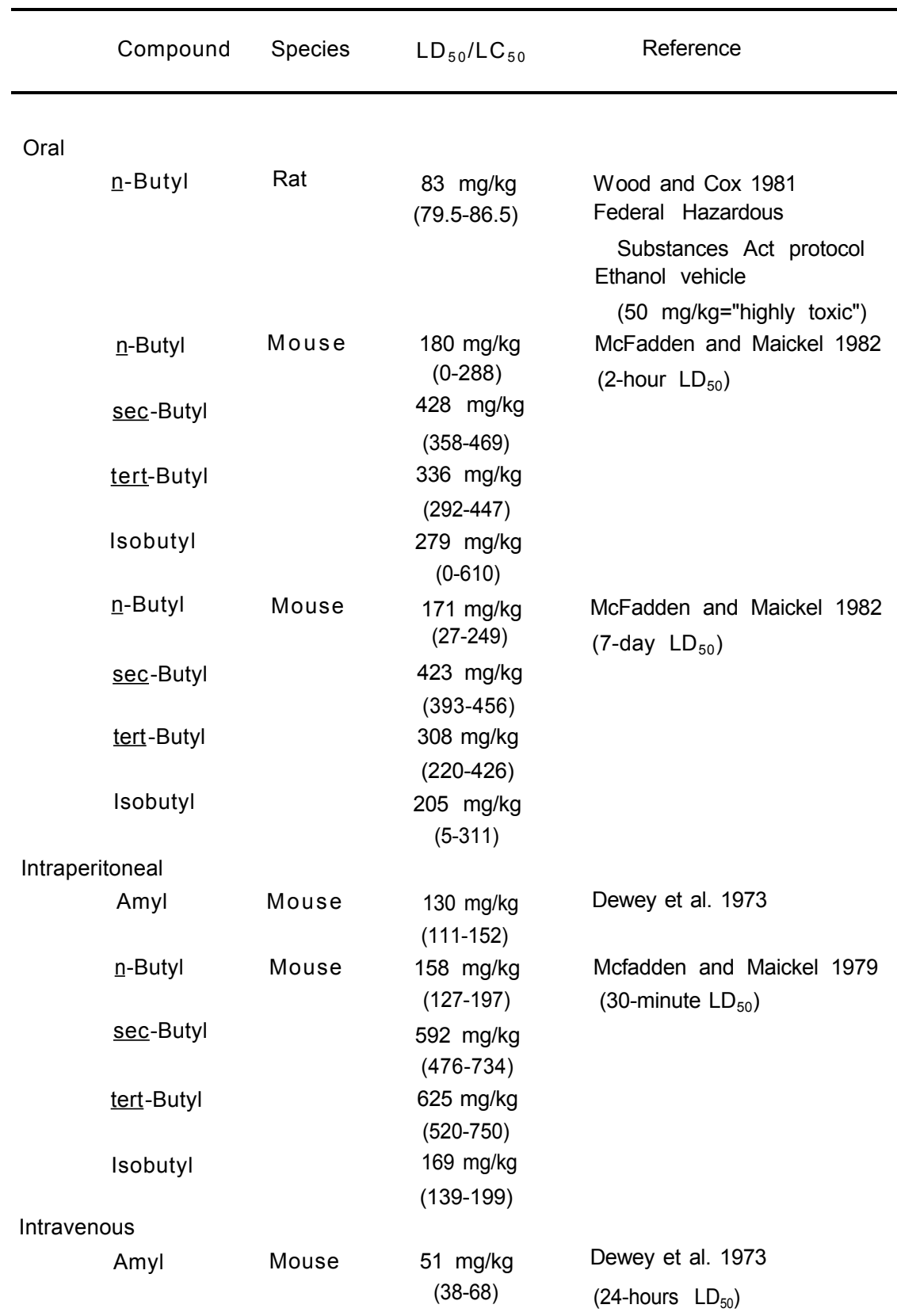


TABLE 1. (Continued)

\begin{tabular}{|c|c|c|c|}
\hline Compound & Species & $\mathrm{LD}_{50} / \mathrm{LC}_{50}$ & Reference \\
\hline \multicolumn{4}{|l|}{ Inhalation } \\
\hline Isbutyl & Mouse & $\begin{array}{r}1346 \mathrm{ppm} \\
(1219-1473)\end{array}$ & $\begin{array}{l}\text { Rees et al. } 1986 \\
\text { (30-minute exposures) }\end{array}$ \\
\hline$\underline{\text { n-butyl }}$ & & $\begin{array}{c}949 \text { ppm } \\
(897-1001)\end{array}$ & \\
\hline Isoamyl & & $\begin{array}{c}1430 \text { ppm } \\
(1302-1559)\end{array}$ & \\
\hline Isobutyl & Mouse & $\begin{array}{l}1033 \text { ppm } \\
(843-1234)\end{array}$ & $\begin{array}{l}\text { McFadden et al. } 1981 \\
\text { (60-minute exposures) }\end{array}$ \\
\hline$\underline{\text { n-butyl }}$ & & $\begin{array}{l}567 \mathrm{ppm} \\
(531-625)\end{array}$ & \\
\hline$\underline{\text { sec-Butyl }}$ & & $\begin{array}{c}1753 \text { ppm } \\
(1552-1964)\end{array}$ & \\
\hline tert-Butyl & & $\begin{array}{l}10852 \mathrm{ppm} \\
(626-15408)\end{array}$ & \\
\hline Methyl & Rat & $\begin{array}{c}176 \text { ppm } \\
(169-183)\end{array}$ & $\begin{array}{l}\text { Klonne et al. } 1987 \\
\text { (4-hour exposures) }\end{array}$ \\
\hline Ethyl & & $\begin{array}{l}160 \mathrm{ppm} \\
(151-169)\end{array}$ & \\
\hline$\underline{\text { n-Propyl }}$ & & $\begin{array}{l}300 \mathrm{ppm} \\
(293-308)\end{array}$ & \\
\hline n-Butyl & & $\begin{array}{r}4210 \mathrm{ppm} \\
(410-431)\end{array}$ & \\
\hline Isobutyl & & $\begin{array}{l}777 \text { ppm } \\
(747-809)\end{array}$ & \\
\hline $\begin{array}{l}\text { Isopentyl } \\
\text { (Isoamyl) }\end{array}$ & & $\begin{array}{l}716 \text { ppm } \\
(702-731)\end{array}$ & \\
\hline$\underline{\text { n-Butyl }}$ & Rat & $\begin{array}{r}1470 \mathrm{ppm} \\
(1226-1823)\end{array}$ & $\begin{array}{l}\text { CPSC memo fro Perez to } \\
\text { Preuss, September } 24,1979\end{array}$ \\
\hline Isobutyl & & $\begin{array}{l}1000 \mathrm{ppm} \\
(815-1255)\end{array}$ & $\begin{array}{l}\text { Federal Hazardous } \\
\text { Substances Act protocol }\end{array}$ \\
\hline Isoamyl & Rat & $\begin{array}{l}1118 \mathrm{ppm} \\
(797-1493)\end{array}$ & (1-hour exposures) \\
\hline
\end{tabular}

Note: $L_{50}=$ Median lethal dose (lethal to 50 percent of test subjects).

$\mathrm{LC}_{50}=$ Lethal concentration, 50 percent. 


\section{REFERENCES}

Bos, J.D.; Jansen, F.C.; and Timmer, J.G. Allergic contact dermatitis to amyl nitrite ("poppers"). Contact Dermetitis 12(2):109, 1985.

Covalla, J.R.; Strimlan, C.V.; and Lech, J.G. Severe tracheobronchitis from inhalation of an isobutyl nitrite preparation. Drug Intell Clin Pham, 15(1):51-52, 1981.

Darling, R.C., and Roughton, F.J.W. The effect of methemoglobin on the equilibrium between oxygen and hemoglobin. Am J Physiol 137:56-68, 1942.

Dewey, W.L; Tucker, LS.; Prange, A; Spaulding, T.; and Chau, T.T. Some behavioral and toxicological effects of amyl nitrite. Res Commun Chem Pathol Pharmacol 5(3):889-892, 1973.

Dixon, D.S.; Reisch, R.F.; and Santinga, P.H. Fatal methemoglobinemia resulting from ingestion of isobutyl nitrite, a "room odorizer" widely used for recreational purposes. J Forensic Sci 26(3):587-593, 1981.

Everett, G.M. Amyl nitrite ("poppers") as an aphrodisiac. In: Sandler, M., and Gessa, G.L., eds. Sexual Behavior Pharmacology and Biochemistry. New York: Raven Press, 1975. pp. 97-98.

Fisher, A.A. "Poppers" or "snappers" dermatitis in homosexual men. Cutis 34(2):118-122, 1984.

Fisher, A.A.; Brancaccio, R.R.; and Jelinek, J.E. Facial dermatitis in men due to inhalation of butyl nitrite. Cutis 27(2):146, 152-153, 1981.

Goedert, J.J.; Neuland, C.Y.; Wallen, W.C.; Greene, M.H.; Mann, D.L; Murray, C.; Strong, D.M.; Fraumeni, J.F., Jr.: and Blattner, W.A. Amyl nitrite may alter T lymphocytes in homosexual men. Lancet 1982-1:412-416, 1982.

Guss, D.A; Normann, S.A.; and Manoguerra, A.S. Clinically significant methemoglobinemia from inhalation of isobutyl nitrite. Am J Emerg Med 3(1):46-47, 1985.

Haley, T.J. Review of the physiological effects of amyl, butyl, and isobutyl nitrites. Clin Toxicol 16(3):317-329, 1980.

Horne, M.K 3d.; Waterman, M.R.; Simon, L.M.; Garriott, J.C.; and Foerster, E.H. Methemoglobinemia from sniffing butyl nitrite. Ann Intern Med 91(3):417-418, 1979.

Israelstarn, S.; Lambert, S.; and Oki, G. Use of isobutyl nitrite as a recreational drug. $\mathrm{Br} J$ Addict 73(3):319-320, 1978. 
Johnston, L.D.; O'Malley, P.M.; and Bachman, J.G. Drug Use Among American High School Students, College Students, and Other Young Adults. National Trends Through 1985. National Institute on Drug Abuse. DHHS Pub. No. (ADM) 86-1450. Washington, DC: Supt. of Docs., U.S. Govt. Print. Off., 1986. 237 pp.

Klonne, D.R.; Ulrich, C.E.; Weissman, J.; and Morgan, AK Acute inhalation toxicity of aliphatic $\left(\mathrm{C}_{1}-\mathrm{C} 5\right.$ nitrites in rats. Fundam Appl Toxicol 8:101-106, 1987.

Lester, D., and Greenburg, L.A. The comparative anoxemic effects from carbon monoxide and methemoglobin. J Pharmacol Exp Ther 81:182-188, 1944.

Lowry, T.P. The volatile nitrites as sexual drugs: A user survey. J Sex Educ Ther 5:8-10, 1979.

Lowry, T.P. Neurophysiological aspects of amyl nitrite. $J$ Psychedelic Drugs 12:73-74, 1980

Lowry, T.P. Psychosexual aspects of the volatile nitrites. $J$ Psychoactive Drugs 14:77-79, 1982.

Lynch, D.W.; Moorman, W.J.; Burg, J.R.; Phipps, F.C.; Lewis, T.R.; Khan, A; Lewis, D.M.; Chandler, F.W.; Kimbrough, R.D.; and Spira, T.J. Subchronic inhalation toxicity of Isobutyl nitrite in BALB/c mice. I. Systemic toxicity. J Taxicol Environ Health 15:823-833, 1985.

Maickel, R.P., and McFadden, D.P. Acute toxicology of butyl nitrites and butyl alcohols. Res Commun Chem Pathol Pharmacol 28(1):75-83, 1979.

McFadden, D.P.; Carlson, G.P.; and Maickel, R.P. The role of methemoglobin in acute butyl nitrite toxicity in mice. Fundam Appl Toxicol 1(6):448-451, 1981.

McFadden, D.P., and Maickel, R.P. Comparative toxicology of butyl nitrites in mice. Toxicol Appl Pharmocol 48:A43, 1979.

McFadden, D.P., and Maickel, R.P. Butyl nitrttes-an example of hazardous, noncontrolled recreational drugs. Res Commun Subst Abuse 3(2):223-236, 1982.

McFadden, D.P., and Maickel, R.P. Subchronic toxicology of butyl nitrites in mice by inhalation. J Appl Toxicol 5(3):134-139, 1985.

Pryor, G.T.; Howd, R.A; Bingham, L.R.; Rebert, C.S.; and Jensen, R.A Biomedical studies on the effects of abused inhalant mixtures. SRI International Project LSU-5956. Final Report. National Institute on Drug Abuse Contract No. 271-77-3402. February 14, 1980. pp. 3659.

Purchase, I.F.H. Studies in kaffircom malting and brewing. XXII. The acute toxicity of some fusel oils found in Bantu beer. SuidAfr Tydskr Geneesk 53:795-798, 1969. 
Rees, D.C.; Coggeshall, E.M.; Dragan, Y.; Breen, T.J.; and Balster, R.L Acute effects of some volatile nitrites on motor performance and lethality in mice. Neurobehav Toxicol Teratol 8:139-142, 1986.

Romaguera, C., and Grimalt, F. Contact dermatitis from nasal sprays and amyl nitrite. Contact Dermatitis 8(4):286-267, 1982.

Romeril, K.R., and Concannon, A.J. Heinz body haemolytic anaemia after sniffing volatile nitrites. Med J Aust 1(6):302-303, 1981.

Shesser, R.; Dixon, D.; Allen, Y.; Mitchell, J.; and Edelstein, S. Fatal methemoglobinemia from butyl nitrite ingestion. Ann Intern Med 92(1):131-132, 1980.

Shesser, R.; Mitchell, J.; and Edelstein, S. Methemoglobinemia from isobutyl nitrite preparations. Ann Emerg Med 10(5):262-264, 1981.

Sigell, LT.: Kapp, F.T.; Fusaro, GA.; Nelson, E.D.; and Falck, R.S. Popping and snorting volatile nitrites: A current fad for getting high. Am J Psychiatry 135(10):1216-1218, 1978.

Smith, M.; Stair, T.; and Rolnick, M.A. Butyl nitrite and a suicide attempt. Ann Intern Med 92(5):714-720, 1980.

Smyth, H.F.; Seaton, J.; and Fischer, L. The single dose toxicity of some glycols and derivatives. J Ind Hyg Toxicol 23:259-268, 1941.

Turner, W. San Francisco fire worst since '06: Razes 25 buidings.

New York Times, July 10, 198.

Wason, S.; Detsky, A.S.; Platt, O.S.; and Lovejoy, F.H., Jr.

Isobutyl nitrite toxicicol by ingestion. Ann Intern Med 92(5):637-

638, 1980.

Wilkins, R.W.; Haynes, F.W.; and Weiss, S. The role of the venous system in circulatory collapse induced by sodium nitrite. $J$ Clin Invest 16:85-91, 1937.

Wood, R.W., and Cox, C. Acute oral toxicity of butyl nitrite. $J$ Appl Taxicol 1(1):30-31, 1981.

\section{ACKNOWLEDGEMENTS}

This work was supported by grants DA04438 and KOZ-DA0017 from the National Institute on Drug Abuse.

\section{AUTHOR}

Ronald W. Wood, Ph.D.

Research Associate Professor

Department of Environmental Medicine

New York University Medical Center

550 First Avenue

New York, NY 10016 
National Institute on
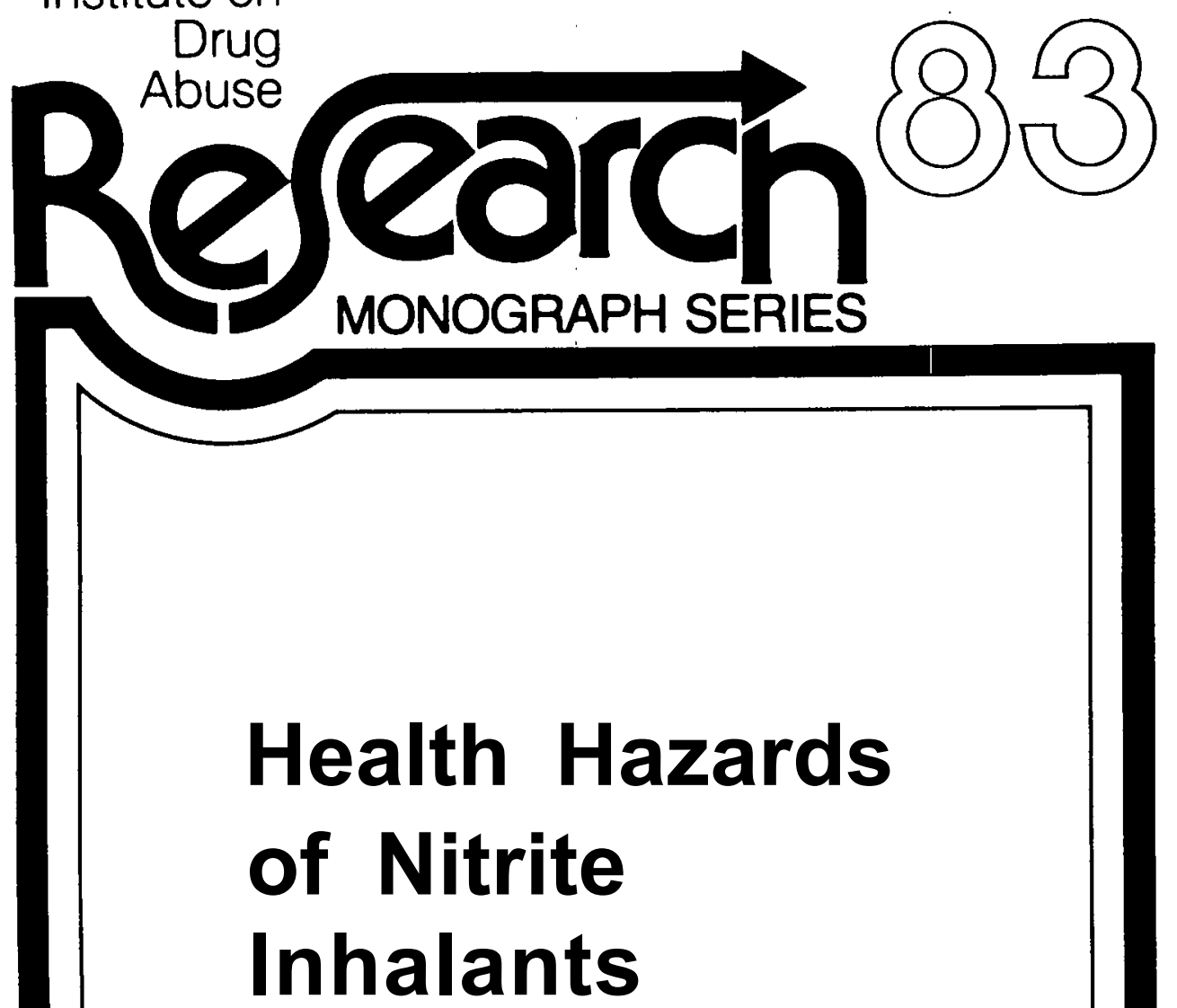


\section{Health Hazards of Nitrite Inhalants}

\section{Editors:}

Harry W. Haverkos, M.D.

Divlsion of Clinical Research

National Institute on Drug Abuse

John A. Dougherty, Ph.D.

Veterans Administration Medical Center

Lexington, KY

\section{NIDA Research Monograph 83}

\section{8}

U.S. DEPARTMENT OF HEALTH AND HUMAN SERVICES

Public Health Service

Alcohol, Drug Abuse, and Mental Health Administration

National Institute on Drug Abuse

5500 Fishers Lane

Rockville, MD 20857 


\section{ACKNOWLEDGMENT}

This monograph is based upon papers and discussion from a technical review on the extent of use and health hazards of nitrite inhalants that took place on March 31, 1987, in Rockville, MD. The meeting was sponsored by the Office of Science and the Division of Clinical Research, National Institute on Drug Abuse.

\section{COPYRIGHT STATUS}

The National Institute on Drug Abuse has obtained permission from the copyright holders to reproduce certain tables, as noted in the text as either previously published or adapted from previously published material. Further reproduction of this copyrighted material is permitted only as part of a reprinting of the entire publication or chapter. For any other use, the copyright holder's permission is required. All other material in this volume except quoted passages from copyrighted sources is in the public domain and may be used or reproduced without permission from the Institute or the authors. Citation of the source is appreciated.

Opinions expressed in this volume are those of the authors and do not necessarily reflect the opinions or official policy of the National Institute on Drug Abuse or any other part of the U.S. Department of Health and Human Services.

The U.S. Government does not endorse or favor any specific commercial product or company. Trade or company names appearing in this publication are used only because they are considered essential in the context of the studies reported herein. Other companies, not named, may also manufacture the products mentioned.

DHHS publication number (ADM)89-1573

Printed 1988, Reprinted 1989

NIDA Research Monographs are indexed in the Index Medicus. They are selectively included in the coverage of American Statistics Index. BioSciences Information Service, Chemical Abstracts, Current Contents, Psvchological Abatracts, and Psvchopharmacology Abstracts. 


\section{Preface}

The National Institute on Drug Abuse (NIDA) is concerned about the acquired immunodeficiency syndrome (AIDS) for two reasons. First, intravenous drug abusers constitute approximately 25 percent of reported AIDS patients in the United States. Human immunodeficiency virus (HIV) infection is transmitted among intravenous drug abusers primarily when contaminated needles and other paraphernalia used to inject drugs are shared. Infected drug abusers are capable of transmitting HIV to their sexual partners during sexual contact and to their unborn children during pregnancy. Second, the use of drugs may expedite disease progression by further decreasing immune function or by acting as the vehicle of transmission of other infectious agents, such as hepatitis B virus, which may also be immunosuppressive. Drugs of abuse may promote the development of malignancies. Nitrite inhalants, commonly used by homosexual men, have been associated with Kaposi's sarcoma (KS) in AIDS. The mechanism of action of nitrites as a cofactor in KS, if any, has yet to be elucidated.

On March 31, 1987, NIDA sponsored a technical review entitled "The Extent of Use and Health Hazards of Nitrite Inhalants." Approximately 25 scientists attended the meeting in Rockville, MD. The purpose of the workshop was to review the status of research regarding nitrite inhalants and their potential public health implications and to set directions for future studies. In part, this meeting was called to provide up-to-date information about nitrite inhalants for NIDA to respond to a congressional request for information as part of the Anti-Drug Abuse Act of 1986.

This monograph is a collection of presentations delivered at the meeting. The chapters are organized to present the history of nitrite use; the basic biochemical, pharmacologic, and toxicologic effects of various forms of alkyl nitrites; the effects of nitrite use on the 
immune system; and epidemiological findings associating nitrite use with KS in AIDS. The purpose of this introduction is to provide an overview of issues and controversies raised at the meeting that are covered in more detail in individual chapters.

There are many controversial issues surrounding nitrites, not the least of which are their current regulatory status. As Guy Newell discusses in his historical presentation, amyl nitrite is a prescription drug, but butyl nitrite, with effects very similar if not identical to the amyl congener, is not considered to be a drug because it is marketed as a "room odorizer." Proposals to regulate the sale of butyl nitrites have been periodically considered by various agencies of the Federal Government.

A series of metabolic and toxicity studies of four nitrite butyl esters in mice was presented by Roger Maickel. The lethality of these compounds was related to rapid hydrolysis to nitrite ions with the subsequent oxidation of hemoglobin to methemoglobin. However, methemoglobin formation cannot account for all toxic effects. While there were wide differences in toxicity, the relative toxic potencies of the four butyl nitrite isomers found in "room odorizers" were maintained under a variety of experimental conditions and routes of administration.

The acute toxicity of nitrites in animals and man was reviewed by Ronald Wood. Skin and tracheobronchial irritations (especially about the nose and lips), burns from accidental ignition, headaches, hypotension, cyanosis, methemoglobinemia, intoxication, and the development of habitual use patterns are possible adverse effects of nitrite inhalation.

Much of the discussion at the meeting focused on two possible pharmacologic mechanisms by which nitrites may be involved in the genesis of KS in AIDS: carcinogenicity and immunosuppression.

Although dependent on an unproven and controversial mechanism, nitrites have been hypothesized to interact with organic amines and amides in vivo to form significant amounts of highly carcinogenic $\mathrm{N}$-nitrosamines. Direct data on the carcinogenicity of nitrites in animals are sparse. However, the in vitro studies of lipid peroxidation and the finding of route-dependent in vivo formation of nitrosamines from amyl nitrite and methylaniline in mice, reported by 
Sidney Mirvish, suggest that the possibility warrants serious investigation. Interestingly, the areas where absorbed concentrations of volatile nitrites would be expected to be highest--the skin surrounding the nose and in the nasal/pulmonary mucosa-are also reported to be the areas in which KS occurs in persons with AIDS. This association logically leads to the hypothesis that there is a causal relationship between nitrites and KS, perhaps mediated by the formation of $\mathrm{N}$-nitroso compounds. How HIV infection initiates or promotes this process is not clear.

Besides participating in the formation of carcinogenic metabolites, alkyl nitrites may increase the likelihood of KS by altering immune function. Dan Lewis, Jesse Ortiz, and Elizabeth Dax studied the effects of nitrites on immunologic function using variations on two basic strategies: first, examination of effects on immunologic components (lymphocyte numbers, thymus weight, etc.) and second, measurement of effects of nitrite pretreatment on the responsiveness of immune system components to challenge with various adjuvants, mitogens, and antigens. Given the complexity of the immune systems in mice and humans, the possible variations in nitrite exposure parameters, the large number of dependent variables and sampling times to choose from, and the diversity of analytic methods available, one might have predicted in advance the divergent results obtained. Lewis reported no significant detrimental effects on the immune systems of mice from exposures to $\mathbf{3 0 0}$ parts per million isobutyl nitrite vapor for 13 weeks. However, the other two researchers showed different patterns of decreases in T-lymphocyte numbers and changes in immune functions after 21 weeks of intranasal amyl nitrite in mice (Ortiz, this volume) or after 13 sessions of amyl nitrite inhalation in human volunteers (Dax, this volume). It is apparent that there is much to learn before the relevance of nitrites to disease processes, such as KS, is understood.

Much has been written about the extent of nitrite use among homosexual men. In addition, household and high school surveys have quantitated use of nitrites among adolescents and young adults, but these surveys have not distinguished use by sexual orientation. In this monograph two surveys of nitrite inhalant use by drug abusers are presented. Richard Schwartz presents data collected from adolescents at a residential drug treatment community in suburban Virginia. Schwartz also assesses the rates of acute toxicity attributed to nitrites among adolescent abusers. Robert Lange presents 
data concerning nitrite use among intravenous drug abusers in treatment from six regions of the United States and among homosexual men in Baltimore. Lange suggests that nitrite use is decreasing among homosexual men because of the fear of an association with AIDS. Nitrite use among intravenous drug abusers is not as extensive as among homosexual men and is not apparently changing.

The unique epidemiology of KS in AIDS suggests that a cofactor is necessary to explain its pathogenesis. Harry Haverkos reviewed the existing epidemiologic studies of nitrite use and KS in homosexual men and found inconclusive results; nitrite use is associated with KS in some studies but not in others. In discussing the variables that may be responsible for the varied results, he ruled out bloodborne infectious agents and focused attention on drug use and sexually transmitted microbial agents as the most likely places to look for the KS cofactor. His discussion points out the difficulties of interpreting questionnaire data when sample sizes are small and methods, populations, and questions vary. Tighter control over survey conditions and standardized methods would make these studies more efficient, but may be impractical to achieve.

An open discussion moderated by Dr. Newell followed the presentations at the workshop. More epidemiologic and laboratory studies are needed to assess the role, if any, of nitrite inhalants as a cofactor in AIDS-related KS. There is a need to develop questionnaires for studies that access nitrite exposure over one's lifetime, analogous to pack-years in cigarette usage. Despite the epidemiologic associations with KS, butyl nitrite has never been tested as a carcinogen. Such studies should be conducted. Studies of animal models infected with retroviruses and challenged with large quantities of nitrites before, during, and/or after retrovirus infection would be useful.

More research is needed to determine the dose-response curve of nitrite inhalation in humans. Many individuals use other drugs, such as alcohol, marijuana, and/or cocaine, with nitrites. What are the effects of these drugs in combination?

Nitrite inhalants are important drugs of abuse in the United States. Their association with KS and AIDS raises an important scientific question about possible synergistic reactions between viruses and chemicals in the development of cancer. It is our hope that this 
monograph will stimulate interest in nitrite inhalant research and attract investigators who can conduct the multidisciplinary research necessary to address the scientific questions raised at this NIDA technical review.

Harry W. Haverkos, M.D.

Clinical Medicine Branch

Division of Clinical Research

National Institute on Drug Abuse

Rockville, MD

John A. Dougherty, Ph.D.

Veterans Administration Medical Center Lexington, $\mathrm{KY}$ 